\title{
Role of Intellectual Capital on Firm Performance (Evidence from Iranian Companies)
}

\author{
Bahram Meihami ${ }^{1}$, Zeinab Varmaghani ${ }^{2}$, Hussein Meihami ${ }^{3}$ \\ 1Department of Accounting, Ghorveh Branch, Islamic Azad University, Ghorveh, Iran \\ 2BA Student of Primary Education, Ghorveh Branch, Islamic Azad University, Ghorveh, Iran \\ ${ }^{3}$ Department of English Language Teaching, Ghorveh Branch, Islamic Azad University, Ghorveh, Iran \\ E-mail address: meyhami4@gmail.com
}

\begin{abstract}
Intellectual capital for companies, particularly manufacturing firms in the third millennium can be considered as a competitive advantage. The purpose of the research is to examine the role of innovation capital in the creation of value for business organizations. Intellectual capital (IC) disclosure has been receiving an increasing amount of attention among the companies around the world such as Australian companies, Italian companies and others. This is due to the new economy driven which is knowledge-based economy where value creation become one of the crucial issues in the world and tends to be based on intangible rather than tangible assets. In this study, a questionnaire was distributed among manufacturing companies have tried to collect statistical information . Questionnaire was divided between manufacturing firms and financial operations managers. The result shows that a company's IC in general has a The significant positive impact on its financial and market performance.
\end{abstract}

Keywords: Intellectual capital; Innovation capital; Value creation; Firm performance

\section{INTRODUCTION}

Intellectual capital (IC) represents the collective knowledge that is embedded in the personnel, organizational routines and network relationships of an organization (Stewart, 1997; Bontis \& Choo, 2002; Kong, 2008). IC has been recognized as an important resource that organizations need to develop to gain sustained competitive advantages (Chen, 2008; Kong \& Prior, 2008; Schiuma \& Lerro, 2008). Intellectual capital can be defined as the 'economic value' of three categories of intangible assets of a company-that includes human capital, organisational capital and social capital collectively. Strategic analysts argue that sustained advantage can occur only in the situations in which physical, human, and organisational capital varies across the firms and where some firms may be unable to obtain necessary resources that are benefiting other firms. Intellectual capital is viewed as a sub-set of intangible capital, where the term intangible relates to assets without physical existence and capital refers to assets retained by the organisation to contribute to future profits. Intangible resources are more likely to produce a competitive advantage because they often are rare and socially complex there by making them difficult to imitate (Black and Boal, 1994). Intellectual capital is "firm's overall or holistic capacity and capability which emerges from its creative and flexible orchestration and coordination of its human capital, innovativeness, competencies and capabilities, streamlined 
processes and expertise. Intellectual capital bundles knowledge resources like constellation of employees, users, processes and technologies and work enabling a company to make a difference to users". In the last decades academia has drawn attention to the role of knowledge in business development. A general consensus is that organizational capabilities are based on the management of knowledge for it is the source of organizational sustainability and competitive advantage. Given the intangible nature of knowledge, different concepts were proposed in the academia and each try to capture a particular phenomenon. Although successful companies realize that investing in knowledge is essential to their ability to create high value products and services. Identifying, valuing, managing intellectual assets is a very difficult task to business managers. Among the different notions, intellectual capital (IC) has been an interesting expression since FORTUNE magazine first published Thomas Stewart's writing in 1991.

\section{PERFORMANCE IMPACT OF INTELLECTUAL CAPITAL}

Intellectual capital forms the root of a corporation - and of a Nation - that supplies the nourishment for future strength and growth. It includes all factors of production, invisible on the traditional balance sheet, but decisive of a company's long term profitability. It is a contemporary topic in the business world. Content and message of intellectual capital has turned traditional accounting upside down. Traditional accounting methods look backwards into the past and measure physical asset only. Intellectual capital includes assets such as brands, customer relationships, patents, trademarks and of course knowledge. The growing discrepancy between market value and book value of a corporation is largely attributed to intellectual capital, the intangibles of business that underpin future growth. The importance of people has become increasingly important (Ahmadi et all,2011). HRM is the key factor for increasing employees' productivity. HR practices turn employees into a resource for development and a source of competitiveness (Nina Poloski Vokic, Maja Vidovic, 2008.) Money talks, but it does not think. Machines perform, often better than human beings can, but they do not invent. Thinking and invention is the assets upon which knowledge work and knowledge companies depend (Stewart, 1997).

There is no longer just a physical employee rather there is knowledge employee. The work is less mechanics and more thinking oriented. As Quinn says, "ideas and intellect, not physical assets built great companies" (Quinn, 1992). If we are to designate the past as "the old economy" and the present and future as the "new economy", the old economy stands for material and the new economy stands for 'knowledge and creativity'. Intellectual capital are receiving increased interest both from academic community and companies because of the influence of innovation and learning on the achievement of competitive advantage for the firm in the new economy. The rise of the "new economy" one primarily driven by information and knowledge, international competitiveness and changing patterns of interpersonal activities is attributed to the increased prominence of intellectual capital management as a management and research topic.

\section{INTELLECTUAL CAPITAL AND VALUE ADDED}

The term intellectual capital for the first time was used in 1969 by economist John Kenneth Albright, in order to explain the gap between book value and market value in institutions. After him, Karl Erik Sveiby Swedes accountant considered the lack of reflecting 
intellectual capital in traditional balance-sheets. In today knowledge-based economy, intellectual capital is the most important capital in every organization and it can effect on the performance of the organization in all aspects (Riahi Balkauie,2003). Also traditional accounting method play an important role in measuring and reporting tangible assets, but these methods in knowledge-based organizations in which knowledge constitutes a major part of its assets, can not measure and report the existing knowledge in them, therefore they need significant changes(Anthony Rojas, 2007). The term "Intellectual Capital" (IC) was first published by John Kenneth Galbraith in 1969 (Hudson, 1993), but Stewart (2001a) claimed the first use back to 1958 when he started intellectual capital study with Itami who later published Mobilizing Invisible Assetsin Japanese in 1980. In general, IC means more than just "intellect as pure intellect" but also a degree of "intellectual action" (Bontis, 1998; Feiwal, 1975). In that sense, intellectual capitalis not only a static intangible asset per se, but an ideological process. It is the kind of movement from "having" knowledge and skills to "using" knowledge and skills. So far there is no generally accepted taxonomy for intellectual capital. A synthesis from extant literature provides three interrelated constructs (Bontis, 1996; Edvinsson and Sullivan, 1996; Ross and Ross, 1997; Stewart, 1995).Among the three Human Capital (HC) comprises the competence, skills, experience, and intellectual agilities ofthe individual employees (Bounfour, 2002; Brooking, 1996; Edvinsson and Malone, 1997; Ross et al., 1997; Stewart, 1997, Sullivan, 2000). Structural Capital (SC) includes processes, systems, structures, brands, intellectual property, and other intangibles that are owned by the firm but do not appear on its balance sheet (Bounfour, 2002; Brooking, 1996; Edvinsson and Malone, 1997; Stewart, 1997; Ross et al., 1997;). A third construct is Social Capital (SC) which resides either at the individual or the organizational level. A greater percentage of present research has examined these forms of intellectual capital in isolation. However, looking at any of these subcategories individually would most certainly result in an incomplete account of an organization' sintellectual capital (Brooking, 1996; Lev, 2001; Ross et al. 1997). Moreover, the property of intellectual capitalis not universal and the evolution of intellectual capital is not a common industry phenomenon. It is therefore necessary for researchers to develop an industry-specific measurement tool. Only periodically examine the data collected would improve the strategic use of an organization's knowledge assets relate to intellectual capital, there are different definitions about this term and thus there is no single and the same definition about it. Some important definitions of intellectual capital are as follows: Intellectual capital, is the source of intangible assets that often is not reflected in the balance-sheet (Eduinson,1997).Intellectual capital includes knowledge, information, intellectual capital and experience that can be used in value creation(Stivart,1999).intellectual capital refers to the all available knowledge assets in an organization through which it can assure its permanent activity as well as gaining a competitive advantage(Anderson,2004). As mentioned above intellectual capital includes three elements: human capital, structural capital and relational capital. Each one is described briefly below: Human capital Human capital represents the stock of staff knowledge in an organization (Benetis \& others, 2002). Human capital forms the foundation of intellectual capital and without that intellectual capital can not be implemented (Chen \& others, 2004). Without intellectual capital, there is no innovation in products, services, and commercial processes (Riahi Balkauie, 2003).In other words, intellectual capital includes knowledge, skills, and abilities of the organization staff that can be used in resolving organizational problems. Because human capital belongs to the organization staff, it can be claimed that this type of capital is not owned by the organization and therefore, with the departure of employees from organizations, this capital also is taken out from the organizations. Thus, organizations seek to prevent capital outflow by converting it to other kinds of capital (Rus \& others,1997). 
Structural (Organizational capital): Organizational capital is an institutionalized knowledge that belongs to the organization and is stored in cases such as: databases, instructions. Rus and colleagues (1997) believe that structural capital refers to "whatever remains in the organization when employees leave there". According to them, structural capital covers organizational capital such as:, intellectual capital, cultural capital, innovation, processes, and it also includes innovation and expansion of capital like: taking out a patent on products and training efforts. This capital is owned by the organization and although through supporting human capital, creates a good ground for better performance on the part of employees. Customer Capital (Relational): Customer capital means the appropriate use of market information in order to attract and retain customers. In fact, this type of investment includes internal and external environment of an organization, and also the organization relationships with customers, competitors, suppliers, trade associations and government (Benetis, 2004). Cases such as customer satisfaction, their loyalty, marketing capabilities, the market severities, the ease of funding, etc. can be included in communication capital. Thus, growth of costumer capital depends on the way human capital and structural capital are supported (Chen \& others, 2004).

\section{MEASURING AND REPORTING INTELLECTUAL CAPITAL}

According to management literature, it is not likely to manage something which can not be measured and reported. Of course there have been already many attempts to measure and report intellectual capital, but they are in their primary stages, so there is a long way to achieve their appropriate positions. To this point, over 30 methods have been introduced for measuring intellectual capital that can be divided into four general categories. A. Direct intellectual capital practices: these methods predict dollar value of intellectual capital through identifying their components. As intellectual capital components are identified, they can be evaluated continuously and directly. They can determine the final value of the organization intellectual capital through a combination (Taliyang, 2011) in excess. By dividing the resulting annual income in excess to the company average cost of capital, the value of corporate intellectual capital is estimated. D- Methods of score (credit) card: in this method different components of intangible assets or intellectual capital are identified and for each of these indicators are provided and or they are displayed in corresponding graphs. The methods of score (credit) card are similar to direct intellectual capital assets but the difference is that in these methods there is no estimation of Rial value of non-tangible assets. The investment market value: This method focuses on calculating the difference between company market value and book value of shares and it categorized the calculated difference as non-tangible assets or intellectual capital. For example, if current value of shares in a company in the stock exchange is equal to 10 million dollar and its book value of shares equals to one billion dollars, then dollar value of intellectual capital of the company will be equal to 9 billion dollars. C- The return of assets method: in this method, the average income before corporate tax in a definite period is divided on the average of the value of physical assets in the same period. Then the resulting number is compared with the average of the return of industry assets. If the resulting difference is zero or negative, the company has no intellectual capital surplus to average of industry and it is assumed that its intellectual capital equals to zero. But if the resulting difference is positive, it is assumed that the company has intellectual capital surplus to the average of industry and it is positive. The difference (positive) is multiplied to the average of physical assets value of the company in the same period to determine the average annual income. 


\section{1. Value Added Intellectual Coefficient Model}

Observing the increased significance of IC in value creation, Pulic $(2000,2002)$ developed a useful measuring tool namely the Valued Added Intellectual Coefficient (VAICTM). Unlike traditional accounting that focuses on business reporting, Pulic (2000) was interested in the driver of value creation and stated that there are two key resources for added value creation: capital employed (consists of physical and financial capital) and intellectual capital (consists of human and structural capital). VAIC has received attention from both academics and in practice for it provides an archetype for peer researchers to build on. For example, Chang (2007) takes R \& D and intellectual property into consideration to improve explanatory power in his pilot study of high technology sector. The result leads to the current study and a modified VAICTM is proposed to include a new intellectual capital component, Innovation Capital. Although there are criticisms on the limitations of VAIC (Andriessen, 2004), a large number of researchers still adopted VAIC in their research (Chen, et al., 2005; Chang 2007; Kamath, 2007; 2008; Chan, 2009). A primary reason is that VAIC uses data from financial statements and minimize potential data subjectivity from using other instruments. A basic tenant for VAICTM is to observe resource efficiency in creating value for the firms. A principle is to calculate the value added (VA) of a firm by subtracting input from output, excluding labor expenses from the input. In financial terms, it is presented as in (1)(S. Chang, 2011)

$$
: \mathrm{VA}=\mathrm{GM}-\text { sgaExp. }+ \text { LExp. }=\text { Operating Income }+ \text { LExp }
$$

where VA is value added; GM is gross margin; sgaExp.: selling, general, and administrative expenses; LExp.:labor expenses that Pulic (2000b) calls human capital. According to Pulic (2000b), the value of human capital(HC) and structural capital (SC) is described by the labor expenses and the difference between VA and HC. From this description, HC and SC are denoted as follows:

$$
\begin{aligned}
& : \mathrm{HC}=\mathrm{LExp} \\
& : \mathrm{SC}=\mathrm{VA}-\mathrm{HC}
\end{aligned}
$$

HC denotes human capital, SC for structural capital; Pulic states that human capital and structural capital are reciprocal. The less the participation of human capital, the more structural capital is involved. The next step is to evaluate social capital, and according to Pulic's VAIC, social capital is calculated by the capital employed which equals the book value of the net assets of the firm.

Research hypotheses:

First hypothesis: There is significant relationship between intellectual capital and employee productivity.

Second hypothesis: There is significant relationship between intellectual capital and product quality.

Hypothesis three: There is a significant relationship between intellectual capital and competitive advantage.

In this study the performance improvement by the three factors to be considered include: employee productivity, product quality and competitiveness. Data collected in this study, the 
sample of basic variables Intellectual capital and corporate performance will be measured, then the next step to investigate the relationship Between these two variables is presented.

\section{DATA ANALYSIS: HYPOTHESIS TESTING}

H0: First hypothesis: There is significant relationship between intellectual capital and employee productivity.

Table1. Tests of First hypothesis.

\begin{tabular}{|c|c|c|c|c|c|c|}
\hline $\begin{array}{c}\text { The } \\
\text { significance } \\
\text { level }\end{array}$ & Possibility & t-test & $\begin{array}{c}\text { Standards of } \\
\text { Deviation }\end{array}$ & Mean & Number & Variable \\
\hline $0 / 05$ & 1 & $21 / 70$ & $0 / 45$ & $3 / 25$ & 90 & $\begin{array}{c}\text { employee } \\
\text { productivity }\end{array}$ \\
\hline
\end{tabular}

According to the statistical results, we can say that the first hypothesis is confirmed. In other words, a significant positive relationship between intellectual capital and the productivity of the employees there.

H0: Second hypothesis: There is significant relationship between intellectual capital and product quality

Table 2. Tests of Second hypothesis.

\begin{tabular}{|c|c|c|c|c|c|c|}
\hline $\begin{array}{c}\text { The } \\
\text { significance } \\
\text { level }\end{array}$ & Possibility & t-test & $\begin{array}{c}\text { Standards } \\
\text { of } \\
\text { Deviation }\end{array}$ & Mean & Number & Variable \\
\hline $0 / 05$ & 1 & $21 / 60$ & $0 / 55$ & $4 / 15$ & 90 & $\begin{array}{c}\text { product } \\
\text { quality }\end{array}$ \\
\hline
\end{tabular}

According to the statistical results, we can say that the first hypothesis is confirmed. In other words, a significant positive relationship between intellectual capital and the product quality.

H0: Hypothesis three: There is a significant relationship between intellectual capital and ompetitive advantage 
Table 3. Tests of three hypothesis.

\begin{tabular}{|c|c|c|c|c|c|c|}
\hline $\begin{array}{c}\text { The } \\
\text { significance } \\
\text { level }\end{array}$ & Possibility & t-test & $\begin{array}{c}\text { Standards of } \\
\text { Deviation }\end{array}$ & Mean & Number & Variable \\
\hline $0 / 05$ & 1 & $15 / 91$ & $0 / 67$ & $3 / 88$ & 90 & $\begin{array}{c}\text { competitive } \\
\text { advantage }\end{array}$ \\
\hline
\end{tabular}

According to the statistical results, we can say that the first hypothesis is confirmed. In other words, a significant positive relationship between intellectual capital and the competitive advantage.

\section{RESULT}

Due to the traditional accounting method imperfectly measure the intangible assets; the study adopts MVAIC method to empirically analyze the relationship of IC components and companies' operating, financial, By taking sample from companies the findings have several important implications. First, the results show a significantly positive association between the capital employed efficiency (CEE) and the companies' operating performance. The findings subvert the prevailing understanding that Intellectual capital, , and were the significant roles in creating value for owners as well as for other owners. However, the association between employee productivity and the companies' operating, financial, and stock market performance is positively significant. This indicates that Tehran semiconductor companies perceive as a source of "value creation" when they outsourced the most parts of manufacturing in overseas market. Finally, the results show that intellectual property rights has a significantly positive association with the companies' operating and performance.

\section{References}

[1] Ahmadi, Freyedon, Behzad Parivizi, Bahram Meihami, Morteza Ziaee, Interdisciplinary Journal of Contemporary Research in Business 4(1) (2012) 894-912.

[2] Bollen L., Vergauwen P., Schnieders S., Management Decision 43(9) (2005) 1161-1185.

[3] Bontis N., There is a price on your head: managing intellectual capital strategically. Business Quarterly (1996).

[4] Bounfour, A. (2002). "How to measure Intellectual Capital's dynamic value: the $I C-d V A L$ approach", presentedat the 5th World Congress on Intellectual Capital, McMaster University, Hamilton, Ontario, Canada.

[5] Brooking A. (1996). Intellectual Capital: Core Assets for the Third Millennium Enterprise. Thompson BusinessPress, London. 
[6] Canibano L., Garcia-Ayuso M., Sanchez M. P., Journal of Accounting Literature 19 (2000) 102-130.

[7] Chan K. H., The Learning Organization 16(1) (2009) 4-21.

[8] Chauvin K. W., Hirschey M., Financial Management 22(4) (1993) 128-140.

[9] Chen M. C., Cheng S. J., Hwang Y., Journal of Intellectual Capital 6(2) (2995) 159-176.

[10] Choudhury Jyotirmayee, International Journal of Business and Management 5(9) (2010).

[11] Firer S., Williams S. M., Journal of Intellectual Capital 4(3) (2003) 348-60.

[12] Hudson, W. (1993).Intellectual Capital: How to Build it, Enhance it, Use it. John Wiely \& Sons, New York, NY.

[13] Kamath G. B., Journal of Intellectual Capital 8(1) (2007) 96-123.

[14] S. Chang William, International Journal of Business and Management 6(2) (2011).

[15] Taliyang Siti Mariana, International Journal of Business and Management 6(12) (2011) 